Article

\title{
Intraspecific Length Variation and Shell Thickness of the Ostracod Cyprideis torosa (Jones, 1850) as a Potential Tool for Palaeosalinity Characterization
}

\author{
Christopher Berndt ${ }^{1, *}$, Peter Frenzel ${ }^{2}$ and Attila Çiner ${ }^{1}$ \\ 1 Eurasia Institute of Earth Sciences, Istanbul Technical University, Maslak, 34469 Istanbul, Turkey; \\ cinert@itu.edu.tr \\ 2 Institute of Earth Sciences, Friedrich Schiller University Jena, Burgweg 11, 07749 Jena, Germany; \\ peter.frenzel@uni-jena.de \\ * Correspondence: berndt@itu.edu.tr; Tel.: +49-1577-935-8317
}

Received: 31 December 2018; Accepted: 11 February 2019; Published: 13 February 2019

\begin{abstract}
Cyprideis torosa (Jones) is a common ostracod species in brackish waters of large parts of the world. The species appears in, but it is not restricted to, marginal marine areas, and it thus plays a significant role in identifying variable impacts between the marine and terrestrial realms as its carapace changes phenotypically under various conditions. This variability could be a highly valuable source of information in palaeoecology. We use valves of this species living in different lagoonal and lacustrine environments of the Kizllırmak Delta at the Turkish Black Sea coast since the Mid-Holocene. By measuring the valve sizes of adult individuals and A-1 instars and documenting the thickness classes of the adult shells we found a good positive correlation between the size of female valves and the prevailing salinity (correlation coefficient: 0.56 ), while such a correlation is lacking for ontogenetic stage A-1. No changes of the height/length ratio of the valves were recognizable along the salinity gradient. Shells are significantly thicker under relatively stable, higher saline conditions, but thinner in highly variable and low saline deltaic lakes. Both morphological features, size and shell thickness of $C$. torosa (Cyprideis torosa), are thus potential tools to give palaeo-environmental information, especially in $C$. torosa-dominated, low diversity marginal marine environments.
\end{abstract}

Keywords: Cyprideis torosa; morphometry; valve size; shell thickness; Holocene; Kızllırmak Delta; Black Sea; Turkey

\section{Introduction}

Ostracoda are small crustaceans (typically $0.5-2.0 \mathrm{~mm}$ long in the adult stage) enclosed by a two-valved mineralized carapace. They populate nearly all aquatic realms [1]. Their highly variable calcareous carapace preserves easily, and thus ostracods show a good geological record since the Palaeozoic times. Based on their wide distribution, often high abundance, and diversity and taxon-specific ecological preferences and tolerances, they are highly suitable for environmental reconstructions [1,2]. An integral part of every ostracod is its carapace as it protects the animal against predators or harsh environmental conditions, plays an important role for the contact with the surrounding environment, supports its mode of life, and gives stability for the benthonic lifestyle $[3,4]$. The identification and use of each ostracod species to reconstruct environments in the geological past is highly based on the morphology of their shells [1].

Ostracod valves grow discontinuously by molting, i.e., their instars shed their valves and calcify new ones in defined ontological stages. There are eight instar stages, and adults are characterized by a strong sexual dimorphism in Cyprideis torosa [5]. The carapace of an ostracod is formed by the uptake of Ca-ions from the surrounding water before or after molting, thus producing a new fully-calcified 
carapace [6]. In this way, the shell chemistry can only be related to the environmental conditions which prevail in this specific timespan [7]. Especially the carbonate availability and construction time determine shell calcification and growth in ostracods as in bivalves alike [8,9], but also the prevailing water temperatures during calcification play a role [10]. While the intraspecific shell thickness of marine taxa is well known to be significantly larger in marine waters than in brackish waters, such intraspecific changes are recognized mostly in mollusks, i.e., bivalves, so far [8].

A common and widely distributed ostracod species is Cyprideis torosa (Jones, 1850). It is recognized as an indicator of environmental changes displayed in its phenotypic morphological adaptation [11]. This species is very common nearly worldwide in marginal marine and paralic environments over a large salinity range from oligohaline to hypersaline water bodies [5,12-15]. High population densities up to several tens of thousands of individuals of this plant detritus-feeding species within one-meter square are seen in stressed environments where other ostracod species are absent [5]. This brackish species lives preferentially in brackish water environments at water depths of 0.5-30 m while reaching high population densities between 3 and $5 \mathrm{~m}$ under $0-25{ }^{\circ} \mathrm{C}$ water temperature [16]. It prefers vegetated, silty, and muddy sand substrates [16].

Several former studies demonstrate a phenotypic salinity-dependency of various morphological shell features in C. torosa. After the first descriptions of the ostracod valve structure [17], three other morphologically variable features on the shell of $C$. torosa were found to be related to the ambient salinity of the surrounding waters. A variable noded character of the valve's morphology appears in individuals of this species living in low-salinity environments which was discussed already in Reference [18]. The living cultures of Reference [19] imply their phenotypic appearance with decreasing salinity below 7\%. Furthermore, the ratio between rounded and non-rounded sieve pores is related to salinity as well [20]. A length variation of the female adult valves was observed by Reference [12]. Boomer et al. [21] gathered new data from modern sediments of different seas for the size-salinity relationship and confirmed the threshold of Reference [12] at about 8\% with small valves above and larger valves below this point. However, there is still a significant lack of data in between, i.e., between 8 and $13 \%$.

The Kizilırmak Delta is a wave-dominated delta at the central Black Sea coast of Turkey (Figure 1) [22]. It is fed by Kizılırmak River, the longest river of Turkey (1355 km long) that flows across the Anatolian Plateau in a large bend and traverses the North Anatolian Fault Zone and Central Pontide Mountains until it mouths into the Sinop Graben in Samsun province where it forms an extensive delta plain. The North Anatolian Fault Zone is indicated to actively uplift the Southern delta plain since the Mid-Pleistocene forming of several terrace levels of palaeo-delta plains [23].

Today, the Eastern delta plain has extensive wetlands (Ramsar site) with nine shallow fresh to brackish lakes (Figure 1) as remnants of the Mid- to Late Holocene lagoon in a semi-arid to semi-humid maritime climate [24-27].

Berndt et al. [23] gave the first insight into the Quaternary fluvio-deltaic development of the Kizilirmak Delta. Berndt et al. [27] analyzed the sediment core BW (41 $34^{\prime} 40^{\prime \prime} \mathrm{N}$ and $\left.36^{\circ} 02^{\prime} 51^{\prime \prime} \mathrm{E}\right)$ at the Eastern Kizilırmak Delta plain dealing with ostracod associations and sieve pore shape analysis of C. torosa to reconstruct the Holocene environmental development of the Kizllirmak Delta (Figure 1). The studied sediment core has been radiocarbon-dated by using shells of Cerastoderma edule (Linné), wood, and paralic peats. It covers the development of the delta plain since about $7.9 \mathrm{ka}$ cal BP with a major hiatus between 7.0 and $5.3 \mathrm{ka}$ cal BP. The palaeo-environment is described to change back-and-forth from a mesohaline to a polyhaline lagoon with up to about $6 \mathrm{~m}$ water depth, and to (near-)oligohaline lakes, which were similar to the recent wetland lakes [27]. According to Reference [27], the main factors controlling the Holocene environments are indicated to be the rising sea level and an increasingly arid regional climate of the Anatolian Plateau. While sea level changes have a major impact until the sea level reached a near-recent level at the latest $5 \mathrm{ka}$ cal BP, the regional climate is the major forcing factor thereafter [27]. 


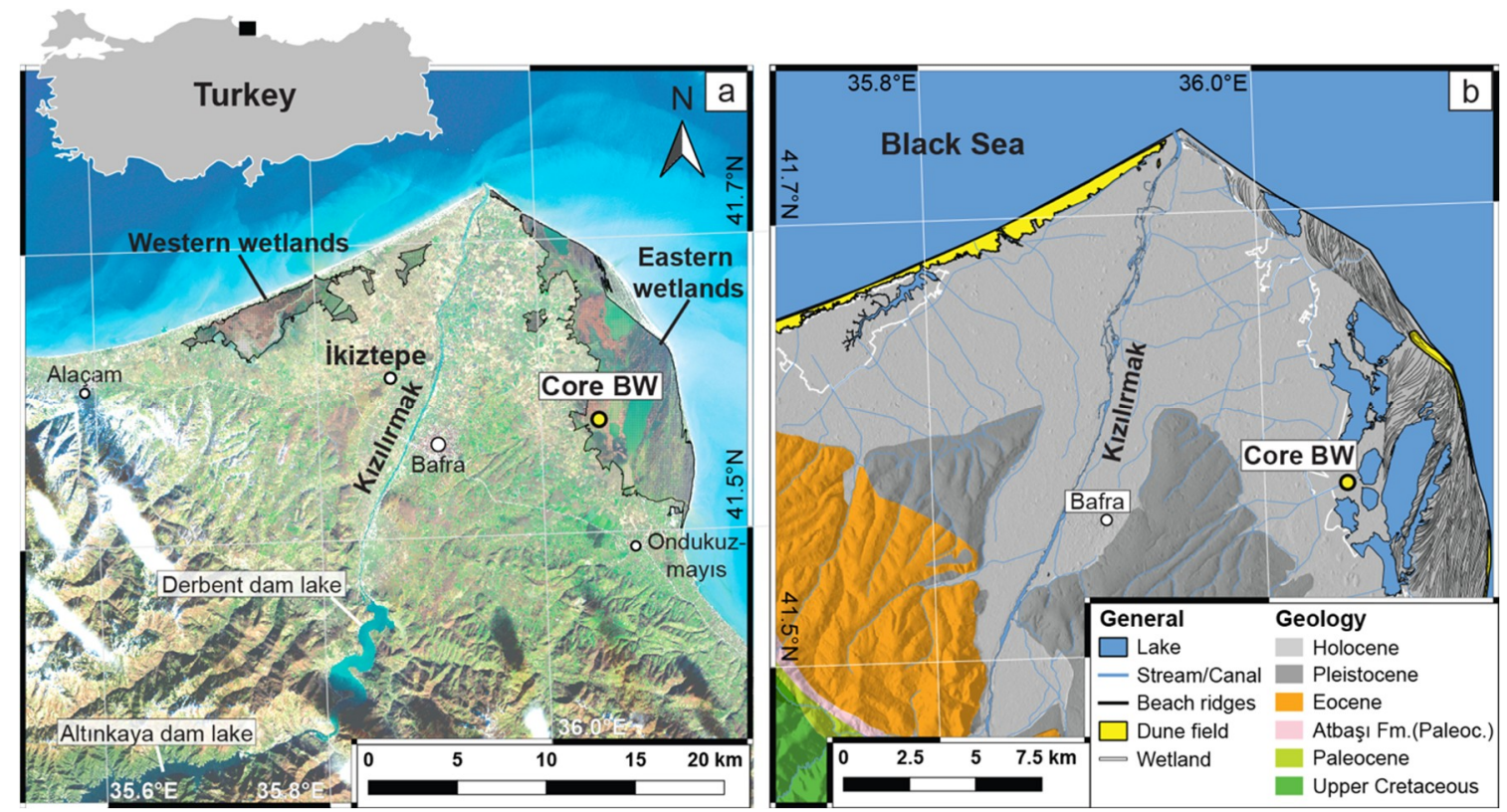

Figure 1. Natural-colored image (a) and geological-geomorphological map (b) of the Kizılırmak Delta with sediment core (BW) (modified from Reference [27]).

Herein, we aim to test the size-salinity relationship of $C$. torosa along the Holocene profile from the Kizılırmak Delta at the Black Sea coast of Turkey to prove its applicability for palaeo-environmental studies. The reconstructed salinity of the related palaeo-environments ranges from oligohaline to polyhaline (ca. 6 to 20\%). Thus, our study is covering the range well with the lack of data in the study of Reference [21] about the variability of carapace size in C. torosa along the salinity gradient. Furthermore, we introduce the thickness of its shells as a new palaeo-environmental indicator in marginal marine settings. Both potential proxies aim to give important information about palaeo-environments, especially within low-diversity or even monospecific assemblages dominated by C. torosa.

\section{Materials and Methods}

We analyzed 17 of already prepared samples taken from the sediment core BW by Reference [27]. Sample preparation, species identification, and counting were previously described in Reference [27]. The samples contain the instars A-3 to A (adult) of C. torosa due to the chosen analyzed fraction of the samples $(>200 \mu \mathrm{m})$. Thus, smaller individuals were excluded during the sieving process.

For the analyses, all available valves of $C$. torosa of the largest two stages were used. The samples along the core are of changing quality for the used methodology. The occurrence of adult valves is limited in many samples; hence, we chose to merge the size data of right and left valves of female individuals, although a size difference of about $3 \%$ was observed that is consistent with the results of Reference [21]. Nine samples in the lower and upper units were excluded from the analysis because of the very low content of usable valves of $C$. torosa.

We measured lengths and heights of all A-1 (penultimate ontogenetic stage) and A (adult) valves in 19 samples by using a light microscope with an ocular scale. Size differences were visible between the adult male and female specimens, but only tentative in the A-1 stage like already observed in Reference [21]. We thus used only the female adult individuals to receive results comparable to the studies of References [12,21], and all specimens of the stage A-1. A linear regression model for the salinity-length relationship was performed using PAST [28].

During the sieve pore analysis of Reference [27], apparent color differences between the valves were recognized using a transmitted light microscope. The adult valves were grouped into three classes according to their translucence. To measure the shell thickness and to exclude a dissolution effect, we took SEM images of two broken valves per valve type. 


\section{Results}

\subsection{Length Variation}

The length of an ostracod is the distance from anterior to posterior margin and the height is the distance from ventral to dorsal margin [29]. The adult specimens of our material vary in size and have mean lengths between 0.77 and $1.036 \mathrm{~mm}$ (female) and 0.903 and $1106 \mathrm{~mm}$ (male). The measurement error is about \pm 2 to $3 \%$.

The mean length of instar A-1 varies between 0.58 and $0.76 \mathrm{~mm}$ and the mean height between 0.36 and $0.44 \mathrm{~mm}$ (Figure 2). The measurement error ranges between \pm 3 and $4 \%$. The largest specimens of this instar are seen in BW-3M and BW-11A, while BW-10C contains the smallest. The deviation between length and height shows a similar pattern like the pure length variations at both instars, although there are small differences - the length deviation of A-1 remains at constant during the middle to upper unit, while the length is slightly increased and the length deviation of the adult specimens is slightly lower in the lowermost two samples and higher at the base of the middle unit with transition to the upper unit. However, there are neither clear patterns nor large deviations recognizable (Figure 2).

\subsection{Valve Thickness}

The observation using SEM revealed that the colorless-translucent valves are the thinnest with about 12-13 $\mu \mathrm{m}$, the brown ones are of intermediate thickness with 18-19 $\mu \mathrm{m}$, and the opaque ones had a thickness with a relatively large range of about 21-30 $\mu \mathrm{m}$ (Figure 3). The threshold between translucent and opaque valves is thus indicated to be at about $20 \mu \mathrm{m}$. The translucent valve type is separated from a brown-translucent valve type by its absence of a distinct/continuous colored appearance (brown) of the valve although this change is rather gradual. Valves with slightly brownish central areas, while the rest of the valve is colorless, are still counted as colorless (Figure 3).

The preservation of the identified valves inspected with the aid of SEM was good, except the thinner ones of the translucent-brown and opaque valves, which have valve surface-parallel dissolution traces (lower middle and lower right images of Figure 3). The opaque valves are two-three times thicker than the colorless translucent valves. We therefore name the categories as thin-walled (colorless-translucent), medium thick-walled (brown translucent), and thick-walled (opaque) specimens. The brownish coloring of translucent valves seems to be rather variable between the valves, but it is always particularly intense in the back of the central muscle scars. None of the shells showed internal sub-layering under the SEM. Dissolution traces were absent in the thin shells and occur only in the medium-thick and thick valves.

The amounts of the different thickness classes are shown in Figure 2. Throughout the lower unit (11.4-8.2 $\mathrm{m}$ below surface), the number of thin valves is predominating with about $83 \pm 6 \%$, while thicker valves are less abundant $(7.2 \pm 6.2 \%$ for medium thick valves and $9.5 \pm 9.3 \%)$. While the number of thick-walled specimens is generally higher than the medium thick-walled ones from the base to BW-10A, the number of medium thick valves is higher above until the top of the lower unit. The middle unit (8.2-3.9 m) shows two samples (BW-7M and BW-6M) with very low amounts (13 and 6.7\%, respectively) of thin-walled specimens and a high amount of medium thick-walled specimens (BW-6A). In samples with very low amounts of thin-walled specimens, the amount of medium thick-walled specimens is highest in BW-7M and low in BW-6M. The amounts of thick-walled specimen are increased throughout the lower part of the middle unit up to $85 \%$. 


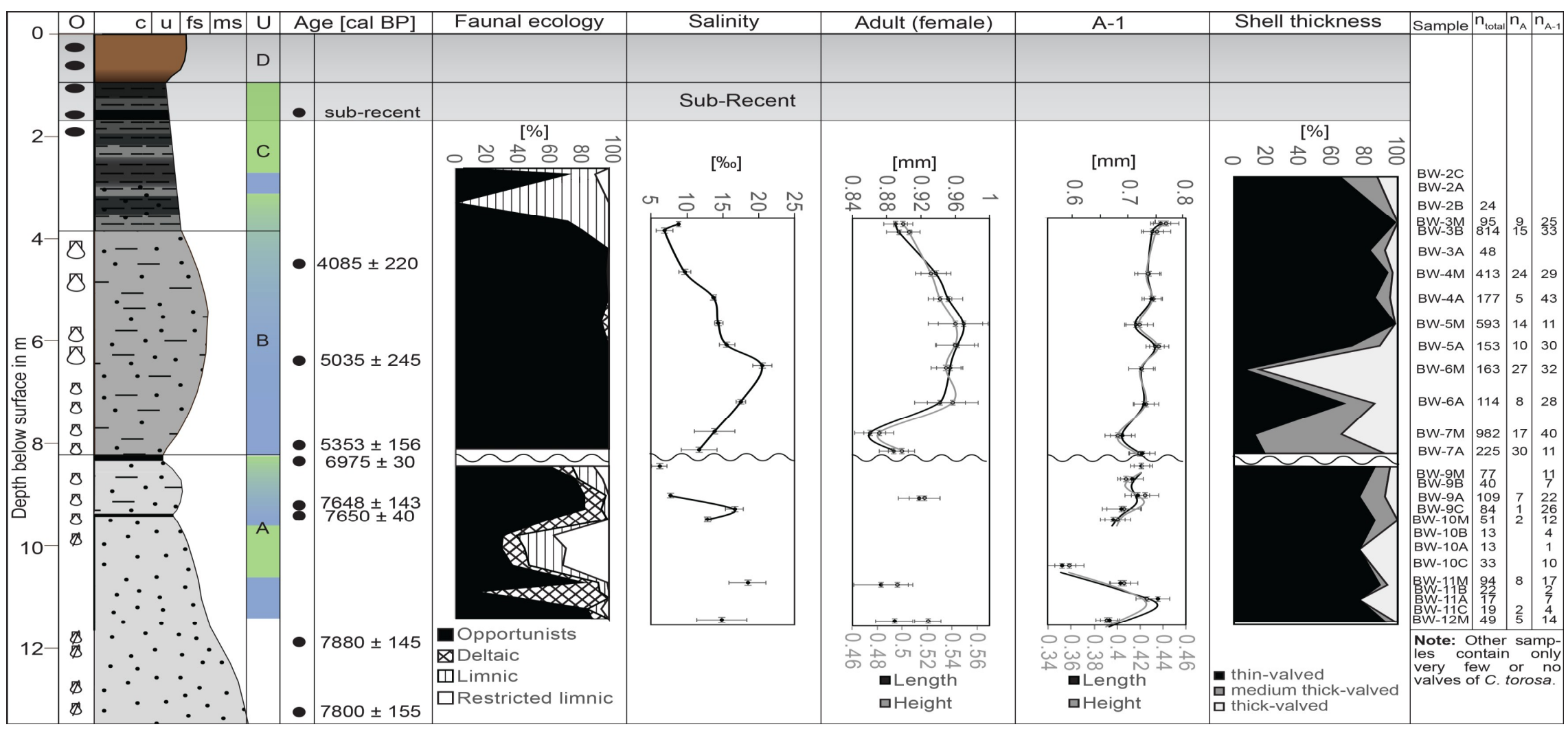

Figure 2. Sediment core BW with lithology appearance of larger shells of C. edule and gravel, sedimentological (A-D) and ecological zonation (blue: Marine, green: Lacustrine), radiocarbon ages, ostracod ecology, reconstructed salinity, length and height measurements of female and instar A-1 C. torosa valves, valves thickness variation, sample names according to their depth below surface, total number of $C$. torosa valves $\left(\mathrm{n}_{\text {total }}\right)$, number of adult $C$. torosa valves $\left(\mathrm{n}_{\mathrm{A}}\right)$ and number of valves of the instar A-1 ( $\left.\mathrm{n}_{\mathrm{A}-1}\right)$ (modified from Reference [27] and combined with new data of this study). 


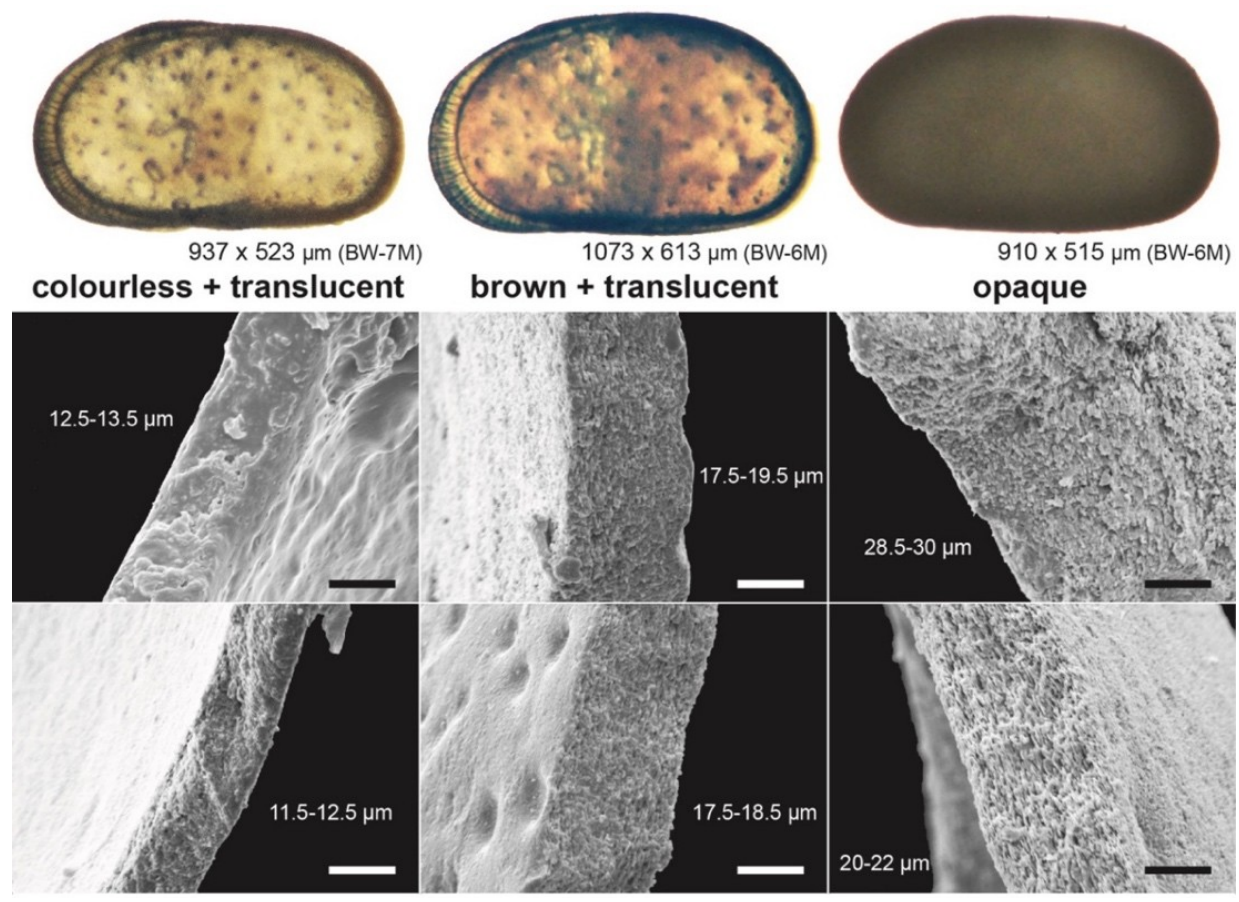

Figure 3. Examples of valve microstructure of female adult valves of $C$. torosa. All scales: $10 \mu \mathrm{m}$.

Above a transitional sample with $73 \%$ of thin-walled specimens accompanied by a slightly increased proportion of medium thick-walled specimens (BW-5A at $5.93 \mathrm{~m}$ ), the amounts of thin-walled specimens are strongly dominant until the upper unit (above $3.9 \mathrm{~m}$ below surface) again (between 83 and 98\%). The top sample (BW-2A at $2.58 \mathrm{~m}$ ) shows slightly lower amounts (63\%) of thin-walled specimens, but the number of analyzed valves is low (8 valves).

\section{Discussion}

This study is a pioneering attempt to apply the size and thickness variation of the valves of C. torosa in a natural setting in a fossil (Holocene) succession and the first study using length and height variations of the A-1 (oldest juvenile) and adult instars.

The length and height variations of both instar A-1 and adult specimens along the section show significant changes. In contrast to the studies of References [12,21], our samples contained only short adult female individuals, and despite the reconstructions of Reference [27] indicated salinities of about 6-7\% for at least two samples (Figures 2 and 4). The intraspecific valve thickness of this species was not described as a phenotypic feature of $C$. torosa so far. This thickness appears to be highly sensitive to environmental changes throughout the regarded period of the Holocene (Figure 2). 


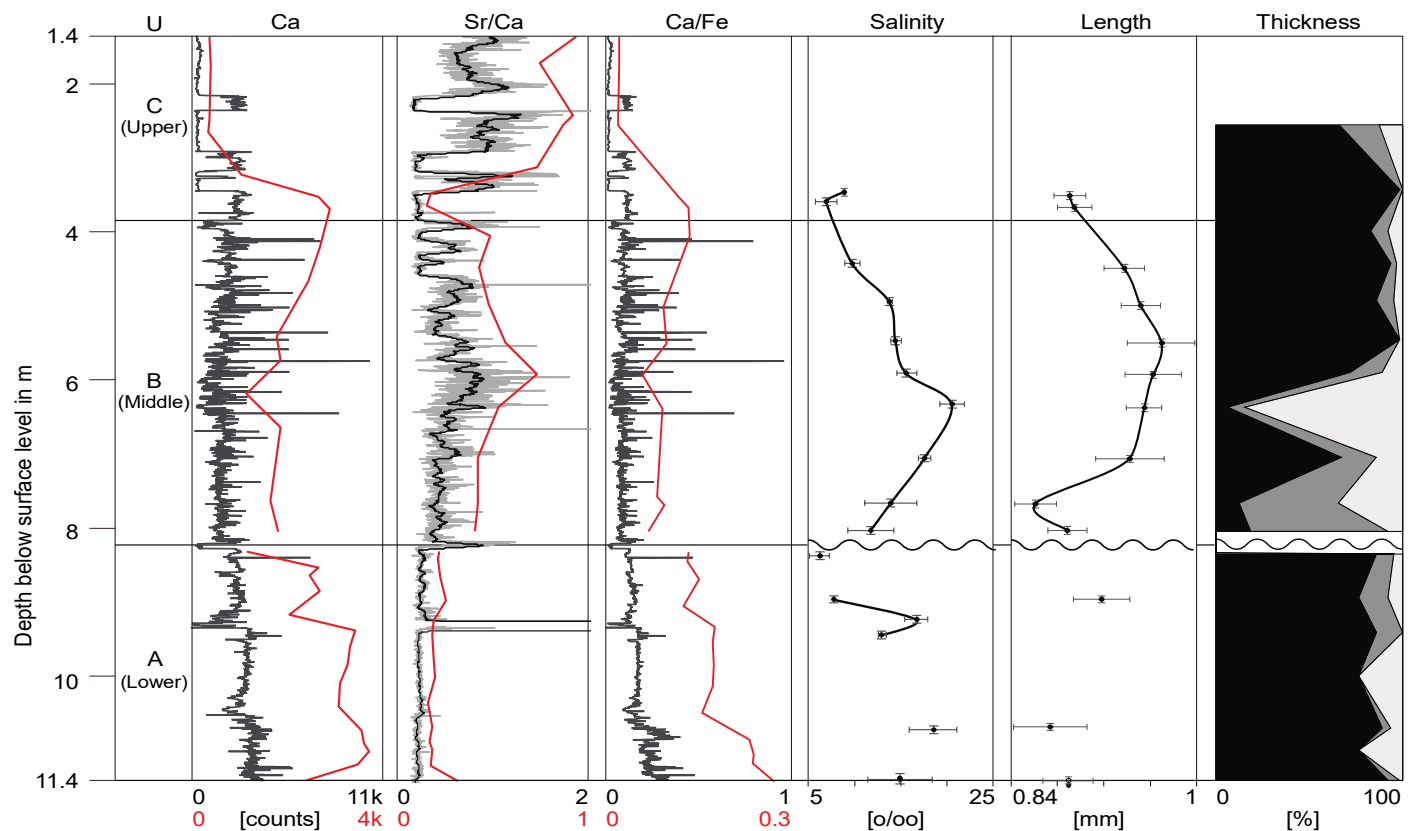

Figure 4. ITRAX-XRF ( $\mathrm{Ca}, \mathrm{Sr} / \mathrm{Ca}$ and $\mathrm{Ca} / \mathrm{Fe}$ ) measurements (XRF data from Reference [27]), valve length and thickness of $C$. torosa (this study). Red lines are mean XRF values for the ostracod sampling ranges. Remark: There are different scales between the ITRAX-XRF record and subsampled mean values.

\subsection{Valve Size-Salinity Relationship}

The length and height on both A-1 and adult specimens correlate very well at 98\% (A-1) and 91\% (female adult) with each other. This implies a primary total size variation instead of a nearly pure lengthening of adult individuals within errors (Figure 5) and is in rough agreement with References [12,21].

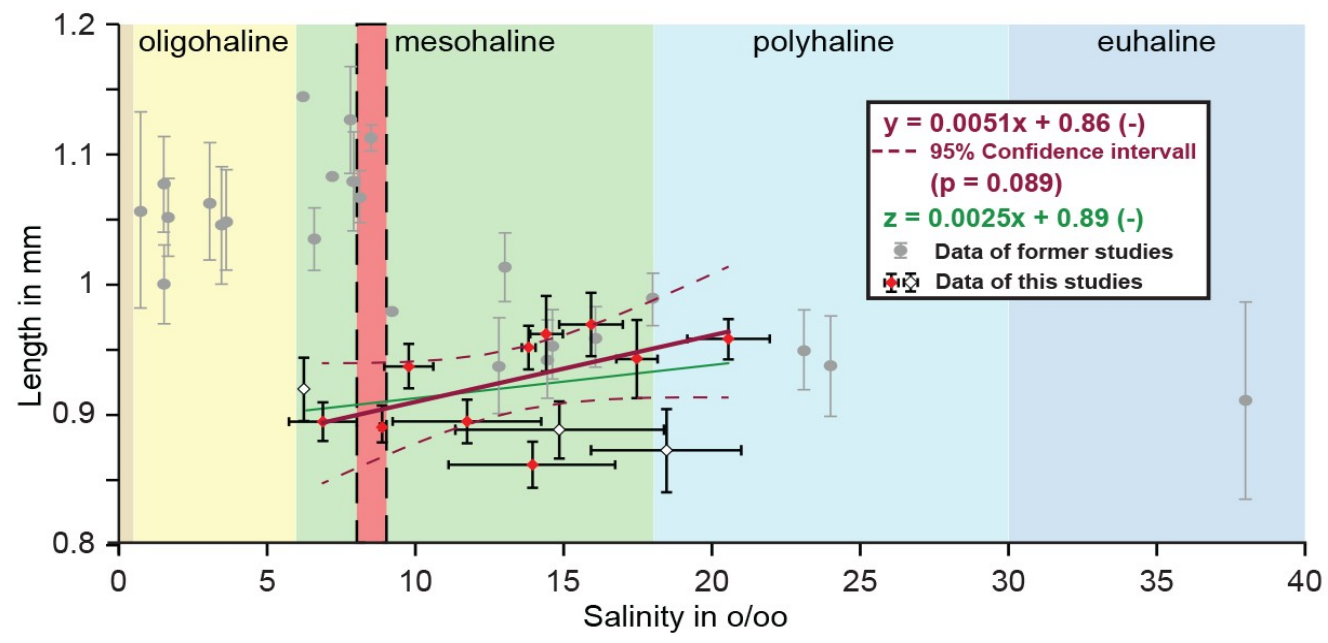

Figure 5. The valve length-salinity relationship with data of former studies in grey (data from References $[12,21])$. The trend line y excludes our whole dataset and the trend line $\mathrm{z}$ includes data from the lower unit.

By comparing the size measurements of adults with the salinity reconstruction of Reference [27], we neglected the lower unit measurements due to their punctual character in a highly variable environment (Figure 5). The numbers of individuals of the lower unit and within the two lowermost samples of the middle unit are small, and the salinity reconstruction of Reference [27] shows larger 
errors. The studied period for the analysis is thus from $5.3 \mathrm{ka}$ cal BP to about $4 \mathrm{ka}$ cal BP in which a major lagoonal phase was prevailing at the Eastern part of the Kizilırmak Delta covering the middle to upper units of the sediment core [27]. This phase contains two environmental shifts. At first, the lagoon formed with an extension of a barrier leading to higher salinities due to evaporation exceeding the open sea conditions at about $5 \mathrm{ka}$ cal BP. Subsequently, the lagoon was highly restricted and an increasing freshwater impact lead to low salinities with a final $\beta$-mesohaline to oligohaline lake phase starting at about $4 \mathrm{ka}$ cal BP [27]. In this part of the sediment core, the average sizes of the female adult individuals correlate well with the salinity in a positive way (Pearson correlation coefficient for height and salinity: 0.54; length and salinity: 0.56), while the size variations of instar A-1 are insignificant, and thus only the size results of female adult measurements are regarded below (Figure 2). Above salinities of $15 \%$, the length of adults is rather variable within a similar range (Figure 2). The error due to size differences between the left and right female valves is lower than the measurement error so that we neglect this potential error. The $p$-value (0.089) of the salinity-length relationship is only slightly above 0.05 , indicating that other factors might influence this relationship as well. The linear regression model accepted a slope equal to zero with a $p$-value of $1.26^{*} \mathrm{e}^{-08}$. We thus cannot exclude an independent result. However, we explain this high $p$-value with the low sample number and an indicated temporal offset between salinity and size. The paleo-environment might still reach (seasonally?) previous temporal salinity values after its reconstructed salinity maximum.

$\mathrm{The} \mathrm{Sr} / \mathrm{Ca}$ ratio is related to evaporation that increases the prevailing salinity but is temperature-dependent as well $[27,30]$ and correlates positively with the reconstructed salinity and length measurements (with a Pearson correlation coefficient of about 0.7 for each) (Figure 4). In contrast, the $\mathrm{Ca}$ content and $\mathrm{Ca} / \mathrm{Fe}$ ratio as indicators for marine influence are negatively correlated to the salinity and $\mathrm{Sr} / \mathrm{Ca}$ in a similar way and to the length to a lower degree (with a Pearson correlation coefficient of -0.3 ) as well (Figure 4). This indicates that the evaporation rates mainly control the salinity of the lagoon. This is explained as an effect of the restriction caused by increased freshwater or lower saline seawater input [27].

The riverine freshwater input, and thus a decrease in salinity, had no significant impact on the size before the salinity dropped below $15.9 \%$ (Figure 2). The difference between sieve pore shapes and size variability might be caused by a different formation time. While the size of the valves is determined during its growth period within the molting process $[6,31]$, the sieve pore shape is finalized during the subsequent valve calcification process [32]. This relationship additionally rules out a major impact of food availability on the size of the detrivorous species.

The deltaic plain system experienced rapid water mass changes due to mainly intra-annual to inter-annual precipitation and insolation changes and storms. Reference [25] shows that the Kızılırmak Delta plain lakes experience large salinity fluctuations between freshwater and intermediate mesohaline conditions in the recent deltaic lakes. This means that the osmoregulation of the local population of $C$. torosa is capable of managing or adapting to such low salinities and transforms its sieve pores accordingly. This high variability may lead to short-term salinities up to about $8 \%$ as well (Figures 2, 4 and 5). It is thus possible that $C$. torosa might molt preferentially to smaller-sized adult individuals which are not expressed in juvenile instars in higher saline conditions while the mean salinity drops below $15 \%$.

Aladin [33] described two kinds of osmotic regulation styles within the euryhaline species C. torosa: Amphiosmotic (oligohaline origin) and confohyperosmotic (brackish with marine origin). This separation agrees well with the former differentiation between $C$. torosa forma torosa, which displays a reaction to low saline environments, and C. torosa forma littoralis, which is dominant in marine environments $[11,19]$. The individuals of our study are smallest during (near-)oligohaline conditions and at significantly lower salinities than the size-break [21]. This might confirm Reference [33], which mentions that $C$. torosa of the Black Sea are mainly amphiosmotics (C. torosa forma torosa). This further implies that both morphotypes are phenotypic variations of one species in shifting salinities by changing their style of osmoregulation [19], or that the populations of different water bodies 
developed specific osmoregulation [33]. This could explain the discrepancy between the results of References [12,21] and ours. However, nodes that appear regularly in C. torosa forma torosa are absent in our study, which might be caused by the lower salinity contrast between marine and terrestrial environments, which show a salinity rarely below $7 \%$, or environments giving sufficient time to molt in preferred conditions [19].

Based on these results, the salinity or the conditions bound to salinity have a significant impact on size variation. For example, Reference [10] showed a strong temperature relationship of Herpetocypris brevicaudata Kaufmann 1900 in a laboratory experiment. During the evolution of the Kizllirmak lagoon, the restriction seems to promote an increase in salinity and increasing variability of surface temperatures in the shallower and smaller water body (compare [34]). Adult C. torosa seem to form larger valves under $\alpha$-mesohaline and more stable conditions [21]. Smaller, oligohaline water bodies with increased seasonal salinity and temperature variability are expected to produce smaller valves instead. In addition, the restriction of the lagoon might cause an oxygen deficiency, which is known to be a critical factor in the growth of mollusks, e.g., References $[35,36]$. However, dominance of $C$. torosa is seen in sub- to anoxic environments like harbor basins [37,38], indicating a high ability to withstand oxygen deficiency. The smaller-sized adults in the lower part of the lagoonal phase of the sediment core BW with an interpreted good connection to the open sea [27] seem to disagree with the major influence of oxygenation on size as well. Furthermore, Reference [12] mentioned a possible dependency on increased environmental stress that is concurrent with the approximation of low saline environments. This seems to be plausible as a cause of smaller valves and a final replacement by other taxa when the salinity becomes too low.

Overall, we observed a positive size feedback on salinity changes in the mesohaline range. This finding is in good agreement with the studies done on mollusks [39,40]. These results fill partly the salinity gap of the former studies of References [12,21]. In contrast to those studies, no break in size variation by salinity was observed, although the mean salinities decreased to even near-oligohaline conditions [27] (Figure 4). The absence of this size break observed by References [12,21] seems to be caused by the adaptation ability of the local population or high variability of the environment. The reconstructed salinity by Reference [27] must be taken as a mean value over a multi-decadal to multi-centennial time period so that a high variability of the salinity can be expected. Nevertheless, a causal dependency between size and osmoregulatory capabilities or stresses of this species in lower salinities needs to be tested in laboratory studies. Furthermore, the sample size is relatively low, and this study deals with material from only one location, so both should be expanded in future studies to test the applicability of this proxy further.

\subsection{Valve Thickness}

The thickness of ostracod shells has been already recognized to be environmentally caused by Reference [41]. Carbonel [42] pointed out that the ornamentation of ostracods is primarily controlled by physiology (intensity of the ornamentation) and genetics (shape of the ornamentation). In addition, References [43,44] described a positive correlation of the reticulation intensity of Cyprideis with an increased ionic concentration in the water (evaporation).

The differentiation of three different classes of valves thicknesses (translucent, brownish-less translucent, and opaque valves) unraveled significant differences along the Holocene sediment record and reflects some of the major ecological variations (Figures 2 and 3). The samples are dominated by thin-walled specimens throughout the lower and beginning in the upper middle unit to the top. Both units of the sediment core show mainly freshwater-influenced, highly variable, and more restricted environments [27]. The thicker valves dominate largely the marine lower part of the lagoon, although some variability prevails.

The pattern of the occurrence of the thicker valves reflects a good connection to the open sea, while rather restricted environments are populated by thinner specimens [27] (Figure 2). Medium-thickness valves appear in large amounts in the more stable, but lower saline part of the lagoon, while thick 
valves dominate increasingly until the highest salinity caused by a further restriction of the lagoon and lack of freshwater influx. This agrees well with the positive valve thickness correlation and ionic concentration of the water [8,42]. In agreement with Reference [9], a better connection to the higher saline open sea and its salinization improves the conditions to form thicker shells, especially in regard to ion concentration, which is crucial for the shell calcification, like calcium. In addition, the available time to calcify the shell is longest within periods of good connection to the sea, and shortest in the highly variable brackish delta plain environment. Both might explain further the dominance of thick-shelled individuals in the lower part of the middle unit. An abundance maximum of thin specimens in between might relate to an increased freshwater input/seasonality of the lagoon.

Furthermore, a good connection to the open sea implies higher oxygenation and lower but more stable temperatures. Both might be necessary to form thicker valves as well. The upper part of the lagoon is indicated to be more restricted so that periods of oxygen deficiency increase due to higher oxygen consumption following high primary productivity and restricted water mass exchange with the open sea. Lower water temperatures trigger a higher solubility of calcium carbonate [45] so that the calcium ion availability is higher and more constant. This could support an easier, and thus thicker, shell calcification.

In addition, taphonomic processes like mechanical destruction and transport effects due to sorting by weight can affect preferably thin and thus more fragile and lighter specimens [46]. This can lead to an under-representation of thinner specimens compared to the thicker, more robust ones. The lower part of the lagoonal phase is more exposed to currents which might rework, carry away, and crush fragile specimens. Indeed, this part of the core contains a sample with a skewed assemblage (BW-6M) and plenty of broken valves (BW-7A). However, other samples showed none of both effects, thus making strong taphonomic alteration improbable.

Based on these implications, the valve thickness might be a good proxy for the differentiation of estuarine water bodies with freshwater influx and marine realms and appears to be a continuation of the loss in ornamentation by decreasing salinity within the mesohaline salinity range. This finding aims to extend the range of the application of the semi-quantitative approach of Reference [43] to reconstruct the (paleo-)salinity by the surface characteristic of this species to mesohaline salinities, especially because the salinity range is characterized by a very low ostracod diversity that makes additional proxies necessary for environmental reconstructions. The number of samples and specimens in our study is relatively low so that future studies with more samples and comparisons between different settings are necessary to validate these preliminary interpretations, which might lead to a reliable and fast quantitative proxy to improve paleo-reconstructions using fossil Cyprideis-dominated associations.

\section{Conclusions}

The current study shows a phenotypic reaction of $C$. torosa in a marginal marine environment driven by the transformation of a relatively open to a restricted lagoon and deltaic lakes in the Eastern Kizilirmak Delta. Good positive coupling of the size of adult specimens of this species in the local population and salinity was observed between about 6 and 20\% (correlation coefficient of salinity to length: 0.56). This coupling seems to originate either directly from salinity changes as the main driving factor or stress that arises in more variable environments. A size break in lower mesohaline salinities, as suggested by former studies, could not be observed. That might be an osmoregulatory effect or result of molting preferences of the local population. Surprisingly, instar A-1 sizes seem to be independent of the surrounding salinity and change in significant levels only in highly variable environments.

The valve thickness seems to work as a simple proxy for evaluating marginal marine environments dominated by freshwater (thin) or marine (thick) influence. Our results imply a similar reaction of C. torosa like mollusks to decreasing or shorter availabilities of sufficient calcium ion concentrations in the habitat by forming thinner shells.

Author Contributions: Conceptualization, methodology, analyses, writing, visualization, interpretation: C.B.; investigation, supervision, writing and interpretation: P.F.; resources, supervision and writing: A.C. 
Funding: This research was funded by European Union as part of the Marie-Curie-ITN project ALErT (Grant FP7-PEOPLE- 2013-ITN, number 607996).

Acknowledgments: We would like to thank G. Ertunç (Istanbul Technical University) and A. Aksu and his drilling team for their help during the sampling campaign. We would also like to thank the Institute of Geosciences, Friedrich Schiller University of Jena for providing a temporary workspace to the main author during the time of data acquisition, analysis and interpretation. We also appreciate comments and suggestions by three anonymous reviewers who greatly improved the paper.

Conflicts of Interest: The authors declare no conflict of interest. The funders had no role in the design of the study; in the collection, analyses, or interpretation of data; in the writing of the manuscript, or in the decision to publish the results.

\section{References}

1. Horne, D.J.; Cohen, A.; Martens, K. Taxonomy, morphology and biology of Quaternary and living Ostracoda. In The Ostracoda: Applications in Quaternary Research; Holmes, J.A., Chivas, A.R., Eds.; Geophysical Monograph Series; American Geophysical Union: Washington, DC, USA, 2002; Volume 131, pp. 5-36.

2. Boomer, I.; Horne, D.J.; Slipper, I.J. The use of ostracods in palaeoenvironmental studies, or what can you do with an ostracod shell? Paleontol. Soc. Pap. 2003, 9, 153-180.

3. Hartmann, G. Zur Morphologie und Ökologie rezenter Ostracoden und deren Bedeutung bei der Unterscheidung mariner und nichtmariner Sedimente. Fortschr. Geol. Rheinl. Westfal. 1963, 10, 67-80.

4. Karanovic, I. Recent Freshwater Ostracods of the World: Crustacea, Ostracoda, Podocopida; Springer Science \& Business Media: The Hague, The Netherlands, 2012.

5. Heip, C. The life-cycle of Cyprideis torosa (Crustacea, Ostracoda). Oecologia 1976, 24, 229-245. [CrossRef] [PubMed]

6. Turpen, J.B.; Angell, R.W. Aspects of molting and calcification in the ostracod Heterocypris. Boil. Bull. 1971, 140, 331-338. [CrossRef]

7. De Deckker, P.; Forester, R.M. The use of ostracods to reconstruct continental palaeoenvironmental records. In Ostracoda in the Earth Sciences; Elsevier: Amsterdam, The Netherlands, 1988; pp. 175-199.

8. Remane, A. Die Biologischen Grenzen Meer-Süßwasser und Meer-Land. Geol. Rundsch. 1958, 47, 11-24. [CrossRef]

9. Keyser, D.; Walter, R. Calcification in ostracodes. Rev. Española Micropaleontol. 2004, 36, 1-11.

10. Roca, J.R.; Wansard, G. Temperature influence on development and calcification of Herpetocypris brevicaudata Kaufmann, 1900 (Crustacea: Ostracoda) under experimental conditions. Hydrobiologia 1997, 347, 91-95. [CrossRef]

11. Meisch, C. Crustacea: Ostracoda. In Süßwasserfauna von Mitteleuropa; Schwoerbel, J., Zwick, P., Eds.; Spektrum Akademischer Verlag: Heidelberg/Berlin, Germany, 2000; Volume 8, 522p.

12. Van Harten, D. Size and environmental salinity in the modern euryhaline ostracod Cyprideis torosa (Jones, 1850), a biometrical study. Palaeogeogr. Palaeoclimatol. Palaeoecol. 1975, 17, 35-48. [CrossRef]

13. Van Harten, D. Cyprideis torosa (Ostracoda) revisited. Of salinity, nodes and shell size. In Proceedings of the Second European Ostracodologists' Meeting; British Micropalaeontological Society: London, UK, 1996; Volume 191, p. 194.

14. Van Harten, D. Variable noding in Cyprideis torosa (Ostracoda, Crustacea): An overview, experimental results and a model from Catastrophe Theory. Hydrobiologia 2000, 419, 131-139. [CrossRef]

15. Mezquita, F.; Olmos, V.; Oltra, R. Population ecology of Cyprideis torosa (Jones, 1850) in a hypersaline environment of the Western Mediterranean (Santa Pola, Alacant) (Crustacea: Ostracoda). Ophelia 2000, 53, 119-130. [CrossRef]

16. Dykan, N. Neogene-Quaternary Ostracodes of the Northern Part of the Black Sea; Publishing House "Chetverta Hvylja": Kiev, Ukraine, 2016; 272p.

17. Müller, G.W. Deutschlands Süßwasser-Ostracoden. In Originalabhandlungen aus dem Gesammtgebiete der Zoologie; Chun, C., Ed.; Zoologica 30, Schweizerbart Science Publishers: Leipzig, Germany, 1900.

18. Van Morkhoven, F.P. Post-Palaeozoic Ostracoda: Their Morphology, Taxonomy, and Economic Use: 1. General; Elsevier: Amsterdam, The Netherlands, 1962; 204p. 
19. Frenzel, P.; Schulze, I.; Pint, A. Noding of Cyprideis torosa valves (Ostracoda)—A proxy for salinity? New data from field observations and a long-term microcosm experiment. Int. Rev. Hydrobiol. 2012, 97, 314-329. [CrossRef]

20. Rosenfeld, A.; Vesper, B. The variability of the sieve-pores in Recent and fossil species of Cyprideis torosa (Jones, 1850) as an indicator for salinity and palaeosalinity. In Aspects of Ecology and Zoogeography of Recent and Fossil Ostracoda; Löffler, H., Danielopol, D., Eds.; Springer Science \& Business Media: The Hague, The Netherlands, 1977; pp. 55-67.

21. Boomer, I.; Frenzel, P.; Feike, M. Salinity-driven size variability in Cyprideis torosa (Ostracoda, Crustacea). J. Micropalaeontol. 2017, 36, 63-69. [CrossRef]

22. Erginal, A.E.; Öztürk, M.Z. Kızılırmak Deltası plaj sırtlarının taramalı elektron mikroskobu analizleri ve tane boyu parametreleri ile incelenmesi (An assessment of beach ridges on the Kizılırmak delta based on scanning electron microscopy analyses and grain size parameters). Türk Coğrafya Derg. 2010, 54, 43-51.

23. Berndt, C.; Yıldırım, C.; Çiner, A.; Strecker, M.; Ertunç, G.; Sarıkaya, M.A.; Özcan, O.; Ozturk, T.; Güneç Kiyak, N. Quaternary uplift of the northern margin of the Central Anatolian Plateau: New OSL dates of fluvial and delta-terrace deposits of the Kizılırmak River, Black Sea coast, Turkey. Quat. Sci. Rev. 2018, 201, 446-469. [CrossRef]

24. Turoğlu, H. Kızllırmak Deltası ve Yakın Çevresinin Jeomorfolojik Özellikleri ve Insan Yaşamındaki Etkileri; Anadolu Araştırmaları; Istanbul University Publications: Istanbul, Turkey, 2010; Volume 4903, pp. 98-111.

25. Ustaoğlu, M.R.; Mis, D.Ö.; Aygen, C. Observations on zooplankton in some lagoons in Turkey. J. Black Sea/Mediterr. Environ. 2012, 18, 208-222.

26. Köse, B.; Ateș, S.; Çelik, H. Determination of late spring frost affections on some grape varieties grown in Samsun. Türkiye Tarımsal Araștırmalar Dergisi 2014, 1, 162-169.

27. Berndt, C.; Frenzel, P.; Çiner, A.; Ertunç, G.; Yıldırım, C. Holocene marginal marine ostracod successions from the Kizllırmak River delta; Implications for depositional environments and sea level changes at the southern Black Sea coast. Sediment. Geol. 2019, in press. [CrossRef]

28. Hammer, Ø.; Harper, D.A.T.; Ryan, P.D. PAST: Paleontological statistics software package for education and data analysis. Palaeontol. Electron. 2001, 4, 1-9.

29. Bradley, P.S. The shell structure of the Ostracoda and its Application to their Palaeontological investigation. Ann. Mag. Nat. Hist. 1941, 8, 1-33. [CrossRef]

30. Rothwell, R.G.; Croudace, I.W. Twenty years of XRF core scanning marine sediments: What do geochemical proxies tell us? In Micro-XRF Studies of Sediment Cores; Croudace, I.W., Rothwell, R.G., Eds.; Springer: Dordrecht, The Netherlands, 2015; pp. 25-102.

31. Martens, K. Effects of temperature and salinity on postembryonic growth in Mytilocypris henricae (Chapman) (Crustacea, Ostracoda). J. Crustac. Boil. 1985, 5, 258-272. [CrossRef]

32. De Deckker, P. Ostracod palaeoecology. In The Ostracoda: Applications in Quaternary Research; Holmes, J.A., Chivas, A.R., Eds.; Geophysical Monograph Series; American Geophysical Union: Washington, DC, USA, 2002; Volume 131, pp. 121-134.

33. Aladin, N.V. Osmoregulation in Cyprideis torosa from various seas of the USSR. Zool. Zhurnal 1989, 68, 40-50.

34. Den Hartog, C. Typologie des Brackwassers. Helgoländer Wiss. Meeresunters. 1964, 10, 377. [CrossRef]

35. Hamburger, K.; Møhlenberg, F.; Randløv, A.; Riisgård, H.U. Size, oxygen consumption and growth in the mussel Mytilus edulis. Mar. Boil. 1983, 75, 303-306. [CrossRef]

36. McClain, C.; Rex, M. The relationship between dissolved oxygen concentration and maximum size in deep-sea turrid gastropods: An application of quantile regression. Mar. Boil. 2001, 139, 681-685.

37. Delile, H.; Mazzini, I.; Blichert-Toft, J.; Goiran, J.P.; Arnaud-Godet, F.; Albarede, F.; Keay, S. Definition of a new approach in ancient harbor geoarchaeology: Geochemistry and ostracod analyses at Portus (Tiber delta, central Italy). In Proceedings of the 17th International Symposium on Ostracoda, Rome, Italy, 23-26 July 2013; Volume 37, pp. 103-105.

38. Berndt, C. Combined Micropalaeontological and Heavy Mineral Investigation of Holocene Sediments from Elaia, the Ancient Harbour City of Pergamum (Turkey). Master's Thesis, Institute of Earth Sciences, Friedrich Schiller University Jena, Jena, Germany, 2014.

39. Remane, A. Die Brackwasserfauna. Verh. der Deutsch. Zool. Ges. 1934, 36, 34-74.

40. Trahms, O.K. Beiträge zur Ökölogie küstennaher Brackwasser. 2. Die Bodenfauna und Bodenflora des Großen Jasmunder Boddens. Arch. Hydrobiol. 1939, 36, 1-35. 
41. Scott, H.W. Shell morphology of Ostracoda. Arthropoda 1961, 3, 21-37.

42. Carbonel, P. Ostracods and the transition between fresh and saline waters. In Ostracoda in the Earth Sciences; Elsevier: Amsterdam, The Netherlands, 1988; pp. 157-173.

43. Carbonel, P.; Pinson, J. Les Cyprideis Témoins de Lévolution des Sels en Milieu Laguno-Lacustre Sous Climat Semi-Aride. In Taxonomy, Biostratigraphy and Distribution of Ostracodes; Krstic, N., Ed.; Serbian Geological Society: Belgrade, SFR Yugoslavia, 1979; pp. 211-217.

44. Carbonel, P. Les Ostracodes et Leur Intérêt Dans la Définition des Écosystèmes Estuariens et de Plateforme Continentale: Essais D'application à des Domaines Anciens; Mémoires de l'Institut de Géologie du Bassin d'Aquitaine, Université de Bordeaux I: Bordeaux, France, 1980; Volume 11.

45. Frear, G.L.; Johnston, J. The solubility of calcium carbonate (calcite) in certain aqueous solutions at $25^{\circ}$. J. Am. Chem. Soc. 1929, 51, 2082-2093. [CrossRef]

46. Kaesler, R.L.; Kontrovitz, M.; Taunton, S. Crushing strength of Puriana pacifica (Ostracoda), an experimental approach to taphonomy. J. Paleontol. 1993, 67, 1005-1010. [CrossRef]

(C) 2019 by the authors. Licensee MDPI, Basel, Switzerland. This article is an open access article distributed under the terms and conditions of the Creative Commons Attribution (CC BY) license (http://creativecommons.org/licenses/by/4.0/). 